\title{
NON-TRADITIONAL SECURITY THREATS IN SOUTH ASIA
}

\section{BASAVARAJESHWARI HALU ${ }^{1} \&$ DR. CHANDRAKANT YATANOOR ${ }^{2}$}

${ }^{1}$ Assistant Professor, Department of Political Science, Government First Grade College, Chincholi, Kalaburagi, Karnataka, India

${ }^{2}$ Professor, Department of Political Science, Gulbarga University, Kalaburagi, Karnataka, India

\begin{abstract}
Every day, at some place or the other, people are killed, starved, raped, confined, displaced etc. There are problems of racial and communal violence, caste discrimination and violation of human rights. There are also threats arising from across borders, like war, terrorism, transnational organised crimes, nuclear holocaust etc. There is scarcity of basic necessities like nutritious food, potable water, shelter, proper medical care etc. There are also threats like degradation of environment, rising global temperatures and climate change. All these are causing severe threat to mankind on one hand and on the other, to the nature, thus making this world insecure. A broader understanding of the concept of security shall help in addressing these issues. This paper has made an attempt to discuss security and security threats which are nontraditional in nature and particularly those to which South Asian nations are prone.

KEYWORDS: Non-Traditional Security, Drug Trafficking, Human Trafficking, Illegal Migration, Food Security, Health Security, Environmental Security
\end{abstract}

Received: Jun 17, 2020; Accepted: Jul 08, 2020; Published: Aug 26 2020; Paper Id.: IJPSLIRDEC20203

\section{INTRODUCTION}

There is no doubt that countries are enjoying their independence, but there are major security threats coming in the way of appreciation of independence. In the present world, independence has not assured security to the nations and to mankind. There are gauntlets of challenges that man has to face for his survival. Security is one of the basic needs of survival, which man has been deprived for various reasons in the present day. The importance of security was stated by Mill (2015) as "Nearly all other worldly benefits which are needed by one person, may not be needed by another; and many of them can if necessary be cheerfully foregone or replaced with something other; but security no person can possibly do without."

\section{THE CONCEPT OF SECURITY}

Security has been the major point of view in International relations. Without security there is no meaning in International Politics. It is a huge challenge for world politics to confer security and maintain the same. The idea of defining security is not definite because the point of view of meaning of security differs in various aspects like individual, national, universe, based on the need. However the definition by Gallie (1956) is considered as 'essentially contested concept'. The word has been derived all the way from Latin - sikernesse (c. 1200), sikerhede (early 13c.), sikerte (early 15c.), mid-15c., "condition of being secure," Legal sense of "property in bonds", "something which secures" is from 1580s, that of "document held by a creditor" is from 1680s. Phrase security blanket in figurative sense is attested from 1966 to "safety of a state, person, etc." is from 1941. ("Security", n.d.)

In early terms, security that meant was with respect to safeguarding of the nation as a whole from wars, 
rather than individual citizen. Various definitions in these terms have been stated. Ian Bellamy defines security as, "a relative freedom from war, coupled with a relatively high expectation that defeat will not be a consequence of any war that should occur" (Bellany, 1982). According to Walter Lipmann, "a nation is secure to the extent to which it is not in danger of having to sacrifice core values if it wishes to avoid war and is able, if challenged, to maintain them by victory in such a war." (Lippmann, 1943). "Security - insecurity is defined in relation to vulnerabilities - both internal and external - that threaten or have the potential to bring down or weaken state structure, both territorial and institutional and governing regimes" Ayoob (1995). Notwithstanding, the view point of security has broadened to include to economic, societal, political and environmental issues, focusing on people rather than positing a state-centric perceptive in security studies deviating military concerns alone (Bilgin, 2005).

Thus we can consider security of nation in two distinct facets - Military threats and non-military threats. Military threats are the traditional threats due to military components especially to expand the territorial reign. Non-military threats are non-traditional threats due to reasons other than military. It threatens the basic survival or well-being of the individual citizens of the nation. MahbubulHaq (1995) interpreted security as not just confined to territory or nation but security to people in their home, jobs, streets, communities, environment. According to UNDP(1994), even the United Nations has mentioned in the UNDP (1994) Development Report: "For too long the concept of security has been shaped by the potential for conflict between states. For too long, security has been equated with threats to a country's borders. For too long, nations have sought arms to protect their security. But for too many people today, a feeling of insecurity arises more from worries about daily life than from dread of a cataclysmic world event."'The views have helped to broaden and modify the ultimatum of the concept of security.

\section{NON-TRADITIONAL SECURITY THREATS}

The non-traditional threats to security are not new in the field of international relations; however, since the world was dominated by traditional security threats until the end of Cold War period, the non-traditional threats were not emphasized. As non-traditional threats are associated with human security, they shouldn't be considered as an opposition to state sovereignty and national security. Territorial security shall continue to be on the list of states' priority; however other security threats have started demanding greater attention. As a result, the word security incorporates a much broader connotation now-a-days, resulting in the growth and development of many new approaches like cooperative security, universal security, human security, comprehensive security, non-traditional security. In spite of the fact that non-traditional security has picked up much consideration these days, yet we lack a precise meaning and definition.

Caballero (2007) says non-traditional security threats may be defined as: "Challenges to the survival and wellbeing of peoples and states that arise primarily out of non-military sources, such as climate change, cross-border environmental degradation and resource depletion, infectious diseases, natural disasters, irregular migration, food shortages, people smuggling, drug trafficking, and other forms of transnational crime."Though these threats arise from various non-military sources, they can be identified by shared characteristics. These threats, being non-military, have no territorial restrictions; so some of them may be domestic and some may arise from across boundaries. The revolution in communication and technology as a result of globalisation, have resulted in rapid transmission of these threats. Terrorism, transnational organised crimes, environmental security, illegal migration, energy security and human security are the six broad branches of non-traditional security. However one size does not fit all. It is not necessary that all nations have similar 
threats. Every country has its own list of threats, which may or may not be common, further they also depend on the regional arrangements as well.

\section{NON-TRADITIONAL SECURITY THREATS IN SOUTH ASIA}

Southern Asia, a region comprising of 8 nations, namely India, Pakistan, Afghanistan, Bangladesh, Sri Lanka, Maldives, Nepal and Bhutan. The region is characterized by high levels of insecurity in interstate, intrastate and human dimensions. South Asia is afflicted by multiple security threats, some of which are traditional in nature and yet, many others are nontraditional in nature. Furthermore, some traditional threats are worsened by the influence of non-traditional threats. Hence the region is vulnerable to both military and human security threats, which have every potential to weaken the security system. While this is the security situation in South Asia, the governments here are involved in huge spending on defence, thereby lacking adequate resources to spend on human security. Along with adequate share in national budget and innovative approaches by the policy makers, a widespread global and regional cooperation to find effective mechanisms to address these issues are urgently required. In this context, the article tries to highlight some of the non-traditional threats to security in South Asia.

\section{Drug Trafficking}

Not only the South Asian region, but the whole world has been threatened by Drug trafficking.South Asia has been geographically positioned between the 'Golden Triangle' and 'Golden Crescent' which are the two large drug producing centres of the world, thus causing a major threat for the region. South Asia has turned out to be a major transit route for the drugs produced in the region. Apart from that, it has also led to the huge accumulation of drugs in the region, the nexus between narcotics and terrorism, insurgency and terrorist activities funded by them are all some of the significant impacts of drug trafficking (Erina, 2017). Alongside socio-eco-political factors like poverty, illiteracy, corruption,most importantly the porous borders are creating add-on effects only to worsen the situation.Dubey (2011) points out that threat to state's security on account of drug trafficking comes from-

- Production and trafficking of drugs from within the state

- When there is drug abuse within the state

- When a stateserves as a transit route for drug trafficking.

It is not only associated with crime and violence, but also linked with terrorist activities, arms and human trafficking; corruption which is threatening security at all levels -national, regional and international. Hence, there is a requirement of a regional and global effort to curb drug trafficking.

\section{Human Trafickking}

Human trafficking is considered to be a serious violation of human security. Trafficking takes place within as well as across borders. According to a report, human trafficking has grown into a global industry worth $\$ 32$ billion and emerged as a fastest growing criminal activity and the second largest crime committed. An estimated count of 2.4 million people all round the world are the victims of this heinous crime, of these around $80 \%$ are victims of sex trade, says the United Nations (2010). Beggary, Domestic help service, illegal organ removal, forced labour and very importantly sexual exploitation are the main factors behind human trafficking. ILO estimates states that, whereas $43 \%$ of all victims are trafficked for sexual exploitation, another $32 \%$ are victims of economic exploitation, the rest being undetermined (Huda, 
2006). Compared to global statistics, in South Asia alone 150,000 persons are trafficked every year (UNDOC, 2010). Some estimates has shown that every year 1 million to 2 million women, men and children are trafficked worldwide, around 225,000 of them are from South Asia.The intensity and magnitude of the problem rises as a result of poor monitoring and evaluation. However it doesn't mean that nothing has been done to address the issue. Additionally efforts are needed to stop this kind of modern slavery. Along with delivering justice, they must be empowered to reclaim their freedom.

\section{Illegal Migration}

Another security issue concerning South Asia is that of migration. This migration of people in large numbers occurs both within and across borders, impacting both the migrants and the sending and receiving nations. The significant issues identified with cross border movement are irregular migration and human trafficking, both of which are illegal and inhumane. The illegal migration poses demographic, social, economic and political threats (Srivastava et al, 2017);itmay also lead to entryof extremist elements into the country and themfurther engaging in terrorist activities and other forms of organised crime, thus threatening the security of the nation. Migration and refugee problems are emerging as a nontraditional threat to security to all the S0uth Asian nations. Though all migrants are not offenders,the malefactors are from among them and as such the need for a permanent solution arises which must be through mutual understanding and collaboration, only then regional peace and prosperity can be restored and security can be ensured at both levels individual and regional. (Bharadwaj, 2016).

\section{Food Security}

Breenie's study on food security expresses the need to feed around 9 million people worldwide by 2020 and the demand for food will increase $60 \%$ more than the present. 'Ending hunger, achieving food security and improved nutrition and promoting sustainable agriculture' has been set as the second goal of the 17 SDGs set by UN which itself highlights the seriousness of the issue. (Breenie, 2016). Food security can be described as a multidimensional concept referring to having adequate affordable food for a healthy life. There are four components describing food security viz., physical access to nutritious food by means of production, aid, or import; economic access by giving purchasing power by means of employment opportunities and social welfare schemes; stability - which means stable and uninterrupted supply with anticipated prices and satisfactory utilisation of food by people which is uninhibited by health and hygiene problems (Maetz, 2013). Clean drinking water, sanitation, and health are preconditions for utilisation. Food insecurity in South Asia is on rise due to overpopulation, stunted agricultural productivity, widespread fluctuations in production of food due to changing weather system, and more importantly climate change. Unfortunately, people afflicted by poverty with little no purchasing power have no access to nutritious food, potable water and proper sanitation; thus they have to compromise on their food security and health expenditures (Suleri, 2015).Today food security has become a priority for every country whether developed or underdeveloped. A collaborative effort uniting the farmers, government, civil society and the private sector, along with partnerships at regional and national levels is needed to address the issue of food and feeding people which largely influences every aspect of economy and society.

\section{Health Security}

South Asia being a densely populated region accounts for around $20 \%$ of the global population. The countries here face common health threats. South Asia being vulnerable to climate change has a higher risk of being inflicted by vector borne diseases. Along with the existing societal and environmental pressure, by 2050 the region will have to face the burden of 
health risks arising from the patterns of weather fluctuations, which is obvious to lower the standard of living of people in some South Asian nations likeBangladesh, India, Pakistan, and Sri Lanka, says World Bank estimates. The health scenario of the region clearly expresses the magnitude of the effects of some diseases like typhoid fever and tuberculosis, notably the region accounts for approximately $40 \%$ of the total TB cases. Furthermore, threats from zoonotic diseases such as Nipah, Crimean-Congo haemorrhagic fever, and Chikungunyaalso exist. (Gronwall et al, 2018).

Occurrence of an epidemic disease best demonstrates the acute need for a guardian of health. According to U S Global Leadership Coalition (2020), in today's globalised world which is so well and inter connected, if there is an outbreak of any pandemic, it can take just36 hours to spread across the world.The recent outbreak of corona virus has now emerged as a major health security concern for the whole world, with South Asia not being an exception. The present situation has made the whole world to rethink about the need for proper investments in the health sector in order to control pandemics and save lives thus ensuring health security along with various other securities.

\section{Environment Security}

South Asia is prone to a wide range of environmental threats which the region must be concerned with. Firstly, the depletion of forest covers in South Asia which directly affects the lives of the people dependent on forest resources. Secondly, the shrinking of the glaciersin the Himalayas, studies says that those rivers having their origin in Himalayas are likely to dry up by the first half of the twenty-fifth century; further glacial melting will result in the rise of sea level which shall lead to submerging of the whole of Maldives and half of the Bangladesh's paddy growing regions (Pandey, 2016) and thirdly, the climate change, which shall threaten the food and health security in the region. Changes in the monsoon cycle, changes in the agricultural pattern, and adverse effects on water systems are all associated to the environmental security threats. The ecological system of the whole region is likely to be devastated as a result of these changes. Thus environmental security has emerged as one of the major security issues in South Asia. An integrated approach towards tackling the threat of environmental security, is needed to secure South Asia

\section{CONCLUSIONS}

Non-traditional security is a key concern, with respect to the whole world in general and South Asia in particular. This needs to be dealt with, as a priority. However the member nations are still extensively concerned about the traditional military threats and are spending a large portion of their resources on defence budgets. This is severely hampering the human development in the region. The new paradigm of human security is not being given due importance mainly because of the unresolved issues in the region, which is causing mistrust among the member nations. These issues may seem to not affect people of other regions, but sooner or later these humanitarian crises will drag the whole world into even more chaos. Hence there is an urgent need to address these non-traditional security threats at national, regional and global levels.

\section{REFERENCES}

1. John Stuart Mill. (2015). On Liberty, edited by Leonard Kahn, Broadview editions, Broadview Press, Canada, 176.

2. W B. Gallie. (1956). Essentially Contested Concepts. Proceedings of the Aristotelian Society, N.S., 56, 167-98.

3. Security. (n.d.). In Online etymology Dictionary. Etymonline.com Dictionary. Retrieved July 21, 2020, from https://www.etymonline.com/word/security, https://www.etymonline.com/word/secure,

4. Ian Bellany. (1981). Towards a theory of International Security, political Studies, 29(1)102. 
5. Rao, YV Balarama Krishna, R. Srinivasa Rao, and VVK REDDY. "ABC algorithm based comparative analysis of optimal SVC and TCSC placement to maximize loadability." International Journal of Electrical and Electronics Engineering Research 4.6 (2014): 53-64.

6. Lippmann Walter. (1943). US Foreign policy Shield of the republic, Boston: Little Brown. Cited in Arnold Wolfers, Discord and Collaboration (Baltimore: John Hopkins University Press, 1962), 150.

7. Mohammed Ayoob. (1995). The Third World Security Predicament, Boulder: Lynne Rienner, 9. ISBN10 1555875769.

8. Bilgin Pinar. 2005. Regional Security in the Middle East. A critical perspective, London: Routledge Curzon. ISBN-13: 9780415613170

9. MahbubUlHaq, Reflections on Human Development. New York: Oxford University Press, 1995. 115.

10. Patel, Thaneswer, et al. "Socio-economic and environmental changes with transition from shifting to settled cultivation in North-Eastern India: an ergonomics perspective." International Journal of Agricultural Science and Research 3.2 (2013): 117-136.

11. United Nations Development Programme. (1994) Human Development Report 1994: New Dimensions of Human Security. Oxford: Oxford University Press. http://www.hdr.undp.org/en/content/human-development-report-1994..

12. Caballero Anthony. M. (2007). Non traditional Security and Multilateralism in Asia: Reshaping the Contours of Regional Security Architecture? The Stanley Foundation.

13. Erina Mahmud. 2017. Transnational Security Local Approaches to Global Threats. BIPPS Commentary. https://www.scribd.com/document/353959948/Transnational-Security-Local-Approaches-by-Erina-Mahmud

14. Dubey Vishal. (2011). Narco Terrorism And Its Impact On India's Security. https://shodhganga.inflibnet.ac.in/bitstream/10603/246882/3/03_abstract.pdf. http://hdl.handle.net/10603/246882

15. United Nations. New York Daily News. 2010. retrieved from https://www.nydailynews.com/news/world/2-4-million-humantrafficking-victims-world-time-u-n-article-1.1055619.

16. Ajaegbu, Charles C. "Foreign Direct Investment (FDI) and Investment Opportunities in Uganda." International Journal of Economics, Commerce and Research 3.5 (2013): 41-55.

17. United Nations Office of Drug and Crime. 2010. South Asia: six countries meet to increase international cooperation against human trafficking and smuggling of migrants. retrieved from http://www.unodc.org/southasia/en/frontpage/2010/March/international-cooperation.html.

18. U.N Warns on South Asia Child Sex. (29 September 2004). BBC News. http://news.bbc.co.uk/2/hi/south_asia/3700110.stm.

19. S. Huda. (2006). Sex Trafficking in South Asia. International Journal of Gynaecology and Obstetrics 94, 374 - 381 , doi:10.1016/j.ijgo.2006.04.027.

20. Srivastava, Ravi, Pandey, Arvind Kumar. (2017). Internal and international migration in South Asia: drivers, interlinkage and policy issues; discussion paper, UNESCO Office New Delhi. https://unesdoc.unesco.org/ark:/48223/pf0000249459

21. Vinod K Bharadwaj. (2016). Migration and Security in South Asia, Emerging Challenges and Concerns. Academia. https://www.academia.edu/6856846/Migration_and_Security_in_South_Asia_Emerging_Challenges_and_Concerns.

22. Keith Breene. 2016. Food security and why it matters, World Economic Forum. https://www.weforum.org/agenda/2016/01/food-security-and-why-it-matters/

23. Food Security - definitions and drivers, http://www.hungerexplained.org/ 
24. Chakraborty, Samarpan, and S. K. Acharya. "Disillusionment, Dissonance and Entropy Amidst Indian Agriculture: The Reflection and Refraction." International Journal of Applied and Natural Sciences (IJANS) ISSN (P) (2018): 2319-4014.

25. AbidQaiyumSuleri. (October 11, 2015). Food insecurity is a non-traditional security threat. The News International. https://www.thenews.com.pk/tns/detail/559558-food-insecurity-non-traditional-security-threat-abid-qaiyum-suleri

26. Gigi KwikGronvall, Brittany Bland, Thomas Inglesby, Anita Cicero. (July 10, 2018). Global Health Security in South Asia, Johns Hopkins Center for Health Security Report from the meeting in Washington, DC, http://www.centerforhealthsecurity.org/our-work/pubs_archive/pubs-pdfs/2018/180913-global-health-security-south-asia.pdf

27. U.S. Global Leadership Coalition. (March 12, 2020). Fact Sheet. The Coronavirus and Global Health Security. https://www.usglc.org/the-coronavirus-and-global-health-security/

28. Chandra Pandey. (2016). Environmental Security in South-Asia. Journal of International Affairs. 1(1). https://www.semanticscholar.org/ 

